\title{
DAUR ULANG AIR SISA PROSES RELAKSASI-PENGHILANGAN KANJI- PEMASAKAN (SIMULTAN) DENGAN CARA KOAGULASI-FLOKULASI MENGGUNAKAN POLY ALUMINIUM CHLORIDE (PAC) UNTUK DIMANFAATKAN KEMBALI SEBAGAI AIR PROSES YANG SAMA DI PT. DX TEKSTIL BANDUNG
}

\author{
Susanti Sundari \\ Fakultas Teknik Program Studi Teknik Industri \\ Universitas Tulang Bawang
}

\begin{abstract}
To overcome the problem of the limited supply of process water because of its dependence on groundwater due to reducing its discharge, stricting provision of government permits in the depthening of bore wells and increasing the cost of retribution for extracting groundwater, an experimental investigation was conducted to explore the possibility of recycling waste water from the preparation textile process namely Relaxing-Desizing-Scouring (simultaneous), in order to be reused as water for similar process and moreover for dyeing process possibility. The method was coagulation-floculation with Poly Aluminium Chloride (PAC) with concentration variation of PAC $0.5 ; 0.7 ; 0.9 ; 1.1 ; 1.3 ; 1.5(\mathrm{~g} / \mathrm{l})$ analyzed, in condition $\mathrm{pH} 8$ where larger floc size is produced at pH 7-9 (Taki Chemical Co.LTD, 1992), and continuing with testing COD, BOD, pH, total hardness, total suspended solid (TSS), chloride levels, and turbidity. In this study, the optimum PAC concentration was obtained, which was $1.3 \mathrm{~g} / \mathrm{l}$ to meet the requirement. The further process was conducted both Relaxing-Desizing-Scouring (simultaneous) and dyeing by using water after treatment, before treatment and waterground from factory to be compared their results. And to determine the success of the water treatment, tests for weight reduction, white degrees and color differences were carried out.
\end{abstract}

Keywords: Coagulation-Floculation, recycling, waste water, Poly Aluminium Chloride

\section{Pendahuluan}

air merupakan salah satu prasarana yang sangat penting dalam melaksanakan proses tekstil terutama proses penyempurnaan tekstil, sejak persiapan, pencelupan, pencapan sampai kepada proses penyempurnaan akhir. Kebutuhan akan air didapatkan dari air tanah (artesis) maupun air permukaan (air sungai) yang sudah mengalami pengolahan terlebih dahulu pada unit permukaan (air sungai), yang sudah mengalami pengolahan terlebih dahulu sehingga dapat memenuhi syarat sebagai air proses agar tidak menimbulkan gangguan terhadap jalannya proses tekstil atau kerusakan pada peralatan yang digunakan.
Sumber air tanah kuantitasnya terus berkurang karena ketergantungan industri terhadap pasokan air tanah yang masih sangat besar, kalau boleh dikatakan $90 \%$ mengandalkan sumber air tanah, sehingga pemerintah semakin ketat dalam pemberian ijin penambahan kedalaman sumur bor dan dinaikannya biaya retribusi pengambilan air tanah. Dengan demikian air menjadi suatu yang mahal dan semakin terbatas perolehannya. Di PT. DX masalah kurangnya air sudah mulai dirasakan. Sistem jalannya proses diatur sedemikian rupa, sehingga dengan jumlah air yang minimum dapat tercapai proses-proses yang diperlukan. Adakalanya dilakukan penundaan proses (misalnya proses 
pencelupan ) berhubung keperluan air pada saat itu sangat besar karena adanya relaksasi kontinyu yang membutuhkan air cukup banyak.

Dalam mengadapi permasalahan keterbatasan persediaan air proses tersebut, perlu dilakukan penelitian mengenai kemungkinan diolahnya kembali (daur ulang) air sisa proses relaksasi agar dapat dimanfaatkan kembali sebagai proses persiapan penyempurnaan, dan kemungkinannya untuk air proses pencelupan. Dilakukan proses daur ulang terhadap air sisa proses relaksasipenghilangan kanji-pemasakan (simultan) dikarenakan air buangan yang dihasilkan volumenya cukup besar \pm 10.000 liter tiap proses pencelupan. Sistem proses daur ulang yang dilakukan dalam proses daur ulang ini adalah proses koagulasi-flokulasi, dimana dengan penambahan suatu zat kimia yang disebut koagulan akan menghubungkan partikel-partikel penyebab kekeruhan air sehingga mudah untuk diendapkan dan akan dihasilkan air yang relatif bersih, yang diharapkan dapat dimanfaatkan kembali untuk proses persiapan penyempurnaan bahkan untuk air proses pencelupan. Jenis koagulan yang digunakan adalah PAC (Poli Alumunium Klorida) yang mampu memberikan daya koagulasi-flokulasi yang lebih kuat dibandingkan dengan garam alumunium biasa dan besi (N.Kumar, 2017). Maksud dari penelitian ini adalah untuk mengetahui kemungkinan daur ulang air buangan sisa proses relaksi-penghilangan kanjipemasakan secara simultan dengan menggunakan PAC (Poli Alumunium Klorida) untuk digunakan kembali sebagai air proses persiapan penyempurnaan dan pencelupan, dan tujuan penelitian ini untuk menentukan kosentrasi pemakaian PAC yang optimum dalam pengolahan air buangan sisa proses relaksi-pengilangan kanji-pemasakan secara simultan.

\section{Tinjauan Pustaka}

\section{Poli Alumunium Klorida (PAC)}

Poli Alumunium Klorida (PAC) merupakan suatu garam basa dari alumunium klorida, yang dibuat dengan tujuan memberikan daya koagulasi dan flokulasi yang lebih kuat dibandingkan dengan garam alumunium biasa dan garam besi. PAC merupakan senyawa polimer kompleks dari polimer aquo-alumunium, sejenis polimer anorganik dengan berat molekul yang tinggi. PAC dirumuskan sebagai : $\quad \mathrm{Al}_{\mathrm{n}}(\mathrm{OH})_{\mathrm{m}} \quad \mathrm{Cl}_{3 \mathrm{n}-\mathrm{m}} \quad$ yang dikombinasikan dengan komponen lainya dalam jumlah yang kecil. Adapun sifat-sifat koagulan ini antara lain:

- PAC bekerja efektif pada range $\mathrm{pH}$ 6-9, ukuran flok yang terbentuk lebih besar dari $\mathrm{pH} 7$ hingga $\mathrm{pH} 9$ (N.Kumar, 2017).

- PAC mampu mengkoagulasi zat tersuspensi dan koloid dengan baik dan menghasilkan flok yang dapat mengendap dengan cepat.

- Dalam pemakaiannya sering tidak memakai koagulan pembantu.

- Kemampuan koagulasinya tidak dipengaruhi oleh temperatur dan memerlukan waktu kontak yang singkat untuk pembentukan flok.

\section{Dasar-dasar Koagulasi dan Flokulasi}

Partikel penyebab kekekruhan air mempunyai ukuran yang beraneka ragam. Untuk menghilangklannya biasanya dilakukan dengan sedimentasi. Untuk partikel yang ukurannya sangat kecil, diperlukan waktu pengendapan yang sangat lama karena kecepatan pengendapannya sangat kecil. Untuk mempercepat pengendapannya perlu diupayakan pembesaran partikel yang dapat dilakukan dengan proses koagulasi-flokulasi. 
Tabel 1. Kecepatan pengendapan berbagai ukuran partikel

\begin{tabular}{|c|c|c|}
\hline Diameter Partikel $(\mathrm{mm})$ & klasifikasi & $\begin{array}{c}\text { Waktu pengendapan untuk tiap } \\
1 \text { feet }\end{array}$ \\
\hline 10 & Kerikil & 0,3 detik \\
1 & Pasir kasar & 3,0 detik \\
0,1 & Pasir halus & 38,0 detik \\
0,01 & Mendap(silt) & 33,0 menit \\
0,001 & Bakteri & 55,0 jam \\
0,0001 & Koloid & 230 hari \\
0,00001 & Koloid & 6,3 tahun \\
0,000001 & Koloid & 66,0 tahun \\
\hline
\end{tabular}

Sumber: American Water Works Association, 1971, hal 70.

\section{Mekanisme koagulasi-flokulasi dengan PAC}

PAC merupakan polimer yang mempunyai muatan positif dan negatif, sehingga dapat mengikat lebih banyak koloid, baik yang bermuatan positif ataupun negatif. Selain itu PAC mempunyai rantai panjang, yang memungkinkan terbentuknya flok yang lebih besar dan lebih cepat mengendap. Adapun pengikatan koloid atau partikel dengan PAC dapat digambarkan sebagai berikut:

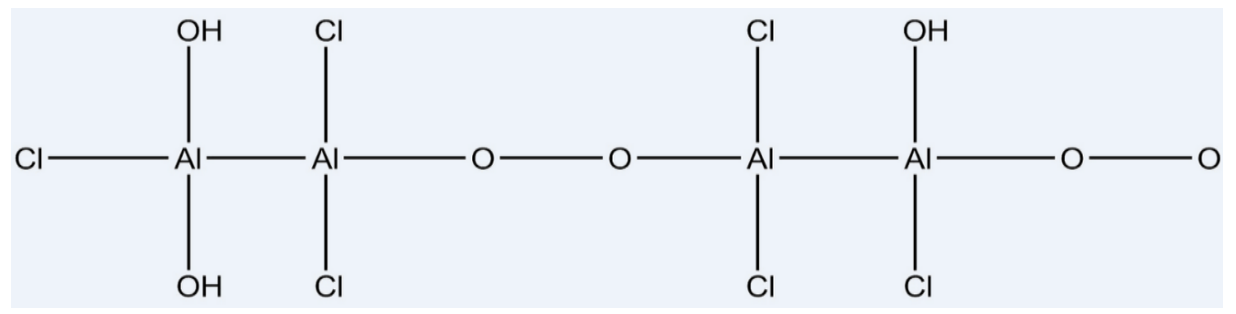

\section{Gambar 1. Rantai PAC}

Sumber : Ivory,Felicitas,Tugas Akhir ITB,hal IV-2

Dalam proses koagulasi,negatif akan membutuhkan ion logam bermuatan positif besar. Dalam penggunaan PAC, Al akan berfungsi sebagai ion tersebut. Koloid dapat terikat atau menempel pada rantai PAC, yaitu pada Al yang menggantikan kedudukan atom $\mathrm{Cl}$. Ion $\mathrm{Cl}$ terlepas ke dalam membentuk $\mathrm{HCl}$, dan kedudukan ion $\mathrm{Cl}$, akan di gantikan koloid negatif. Koloid bermuatan positif terikat dengan rantai ini dengan menggantikan kedudukan atom $\mathrm{H}$ yang berikatan dengan $\mathrm{O}$. Ion $\mathrm{H}^{+}$akan terlepas ke dalam larutan.Dengan sifat-sifat PAC yang ampholit, maka PAC dapat mengikat lebih banyak partikel, dan dengan rantai panjangnya PAC menghasilkan flok yang lebih besar dan lebih cepat mengendap seiring dengan besar nya flok 
itu. Di samping itu,kecepatan pengadukan sangat mempengaruhi pertumbukan flok. Dimana bila kecepatan pengadukan itu terlalu lambat, akan mengakibatkan terlalu terlambatnya pertumbukan flok. Di lain pihak,bila kecepatan pengadukan ini terlalu besar,akan mengakibatkan terpisahnya kembali flok-flok yang telah bergabung.

Di dalam flokulasi, benturan atau kontak antar partikel dapat terjadi melalui 3 cara yaitu :

- Kontak yang diakibatkan oleh adanya gerak termal (panas), yang di kenal sebagai gerak Brown. Flokulasi yang terjadi oleh gerak Brown ini lebih di kenal sebagai 'flokulasi parikenetik'.

- Kontak yang diakibatkan oleh adanya gerak media (air), misalnya diakibatkan oleh pengadukan. Flokulasi yang disebabkan oleh gerak media, dikenal sebagai 'Flokulasi Ortokinetik'.

- Kontak yang terjadi akibat kecepatan menendap masingmasing partikel yang tidak sama.

Cara pertama dan kedua, terjadi dalam proses pembentukan mikroflok dan penggabungan mikroflok. Sedangkan cara ketiga, biasanya terjadi pada saluran efluen dari bak pengaduk dan di dalam bak sedimentasi.

\section{Metodologi Penelitian}

Air buangan proses relaksasipenghilangan kanji-pemasakan (simulltan) diolah dengan cara koagulasi-flokulasi dengan metode Jar test. Konsentrasi PAC (Poli Alumunium Klorida) sebagai zat koagulan divariasikan dari 0,5;0,7;0,9;1,1;1,3;1,5 (g/l). Pada tahap awal dilakukan percobaan pendahuluan terhadap air buangan berupa pengujian kesadahan total, $\mathrm{pH}, \mathrm{KOK}, \mathrm{KOB}_{5}$, dan padatan totalnya. Dengan data yang dihasilkan dapat digunakan dalam memperkirakan variasi konsentrasi PAC yang diambil.
Percobaan berikutnya adalah melakukan pengolahan terhadap air buangan dengan variasi konsentrasi 0,$5 ; 0,7 ; 0,9 ; 1,1 ; 1,3 ; 1,5(\mathrm{~g} / \mathrm{l})$, dan $\mathrm{pH}$ diatur pada kondisi $\mathrm{pH} 8$ dimana terbentuk flok yang lebih besar pada $\mathrm{pH}$ 7-9. Proses pengolahan dilakukan dengan alat Jar test.

Pengujian dilakukan terhadap air yang sudah mengalami pengolahan dengan cara koagulasi dalam menentukan konsentrasi PAC optimum berupa pengujian kesadahan total, KOK/COD (Kebutuhan Oksigen Kimia), $\mathrm{KOB}_{5} / \mathrm{BOD}$ (Kebutuhan Oksigen Biologi, 5 hari), $\mathrm{pH}$, nilai kesadahan, kadar klorida, dan padatan total.

Untuk mengetahui kemungkinan penggunaan kembali air olahan tersebut, terhadap air olahan konsentrasi PAC optimum dilakukan percobaan baik untuk proses penghilangan kanji-pemasakan (simultan), maupun untuk proses pencelupan pada kain polister - CD polister. Proses penghilangan kanjipemasakan (simultan), serta pencelupan 3 macam air yaitu, air buangan (sebeluim diolah), air olahan dengan konsentrasi PAC optimum, dan air proses yang tersedia di pabrik. Juga dilakukan pengujian pada kain yang sudah mengalami proses penghilangan kanji-pemasakan (simultan) dan pencelupan dengan uji pengurangan berat, derajat putih dan beda warna.

Metoda pengujian yang dilakukan terhadap air hasil pengolahan air buangan adalah: Kesadahan Total, Kadar Klorida, Zat Padat Total, $\mathrm{KOB}_{5}$, KOK dan Nilai Kekeruhan. Dan Pengujian-pengujian yang dilakukan terhadap kain yang mengalami proses penghilangan kanji-pemasakan (simultan) dan pencelupan dengan menggunakan air buangan (sebelum proses), air olahan dengan konsentrasi PAC optimum, dan air proses yang tersedia di pabrik, antara lain:

- Pengurangan Berat. Penentuan berdasarkan pada persentase berat yang berkurang setelah dilakukan proses penghilangan kanjipemasakan (simultan) 
- Derajat putih. Penentuan nilai derajat putih diambil dari harga (Yfilter green) terhadap kain sebelum dan sesudah dilakukan proses penghilangan kanji-pemasakan (simultan).
- Beda warna.Pengujian didasarkan pada nilai $\Delta \mathrm{E}$ warna terhadap kain standar pembanding yang dicelup dengan air proses pabrik.

\section{Diagram Alir}

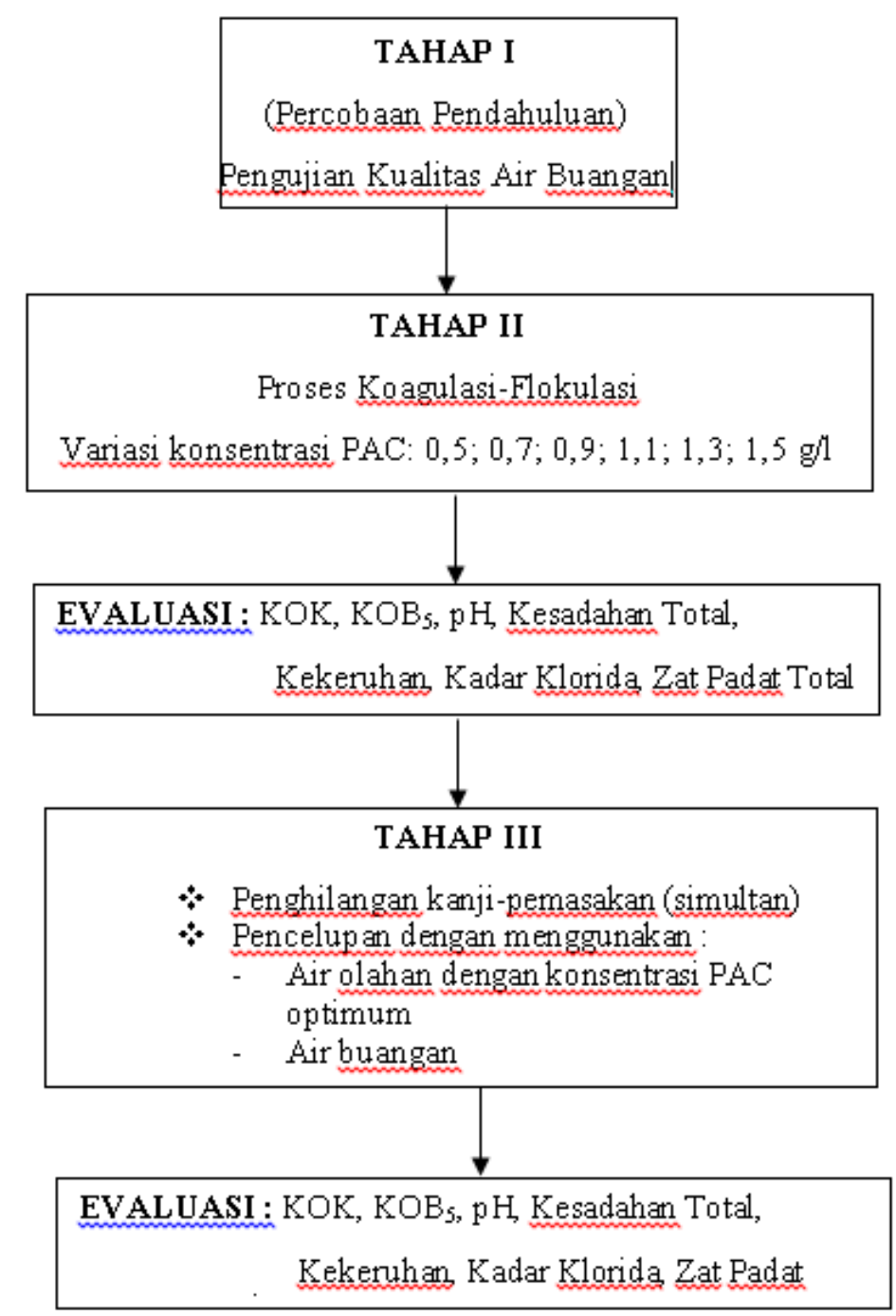

\section{Gambar 2. Diagram Alir Penelitian}

\section{Hasil dan Pembahasan}

Data hasil penentuan Kesadahan Total yang dinyatakan dalam $\mathrm{mg} \mathrm{CaO} / \mathrm{l}$, Nilai Kekeruhan dinyatakan dalam NTU, Kadar Klorida dalam mg/l, penentuan Zat
Padat Total dalam mg/l, $\mathrm{KOB}_{5}$ dalam $\mathrm{mg}$ $\mathrm{O}_{2} / \mathrm{l}$ dan $\mathrm{KOK} \mathrm{mg} \mathrm{O}_{2} / \mathrm{l}$, pada berbagai variasi konsentrasi PAC dapat dilihat pada Tabel. 2 berikut: 
Tabel 2.Data Hasil Pengujian Air

\begin{tabular}{|c|c|c|c|c|c|c|c|c|c|}
\hline \multirow{2}{*}{ PENGUIIAN } & \multirow{2}{*}{ SATUAN } & \multicolumn{6}{|c|}{$\begin{array}{c}\text { Air Olahan } \\
\text { Variasi Konsentrasi PAC }(\mathrm{g} / \mathrm{l})\end{array}$} & \multirow{2}{*}{$\begin{array}{c}\text { AIR } \\
\text { BUANGAN } \\
- \\
\end{array}$} & \multirow{2}{*}{$\begin{array}{c}\text { BATAS } \\
\text { MAKSIMUM } \\
- \\
\end{array}$} \\
\hline & & 0,5 & 0,7 & 0,9 & 1,1 & 1,3 & 1,5 & & \\
\hline Kesadahan Total & $\mathrm{mg} \mathrm{CaO} / \mathrm{l}$ & 60,8 & 60,9 & 60,8 & 61,0 & 60,9 & 60,8 & 60,8 & 70 \\
\hline Kekeruhan & NTU & 2,09 & 1,39 & 1,23 & 1,07 & 0,02 & 0,03 & 9,23 & $5 \mathrm{mg} / 1$ \\
\hline Kadar Klorida & $\mathrm{mg} / \mathrm{l}$ & 91 & 193 & 214 & 226 & 244 & 289 & - & 250 \\
\hline Zat Padat Total & $\mathrm{mg} / \mathrm{l}$ & 2726 & 2718 & 2544 & 2034 & 1892 & 1878 & 7650 & 500 \\
\hline $\mathrm{KOK} / \mathrm{COD}$ & $\mathrm{mg} / \mathrm{O}_{2} / \mathrm{l}$ & 2608 & 2560 & 1872 & 1668 & 1400 & 1432 & 2932 & - \\
\hline $\mathrm{KOB}_{5} / \mathrm{BOD}$ & $\mathrm{mg} / \mathrm{O}_{2} / \mathrm{l}$ & 261 & 176 & 113 & 78 & 72 & 61 & 360 & - \\
\hline $\mathrm{pH}$ & - & 8 & 8 & 8 & 8 & 8 & 8 & 10,8 & $7-9$ \\
\hline
\end{tabular}

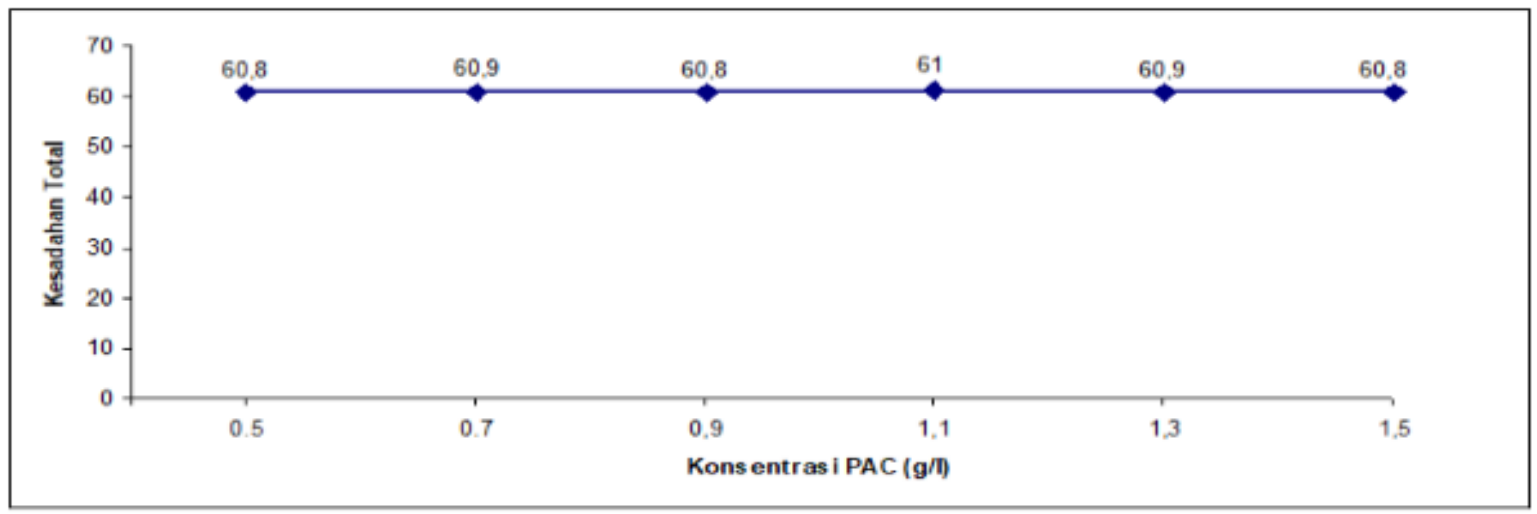

Gambar 3. Grafik Pengaruh Konsentrasi PAC terhadap Kesadahan Total

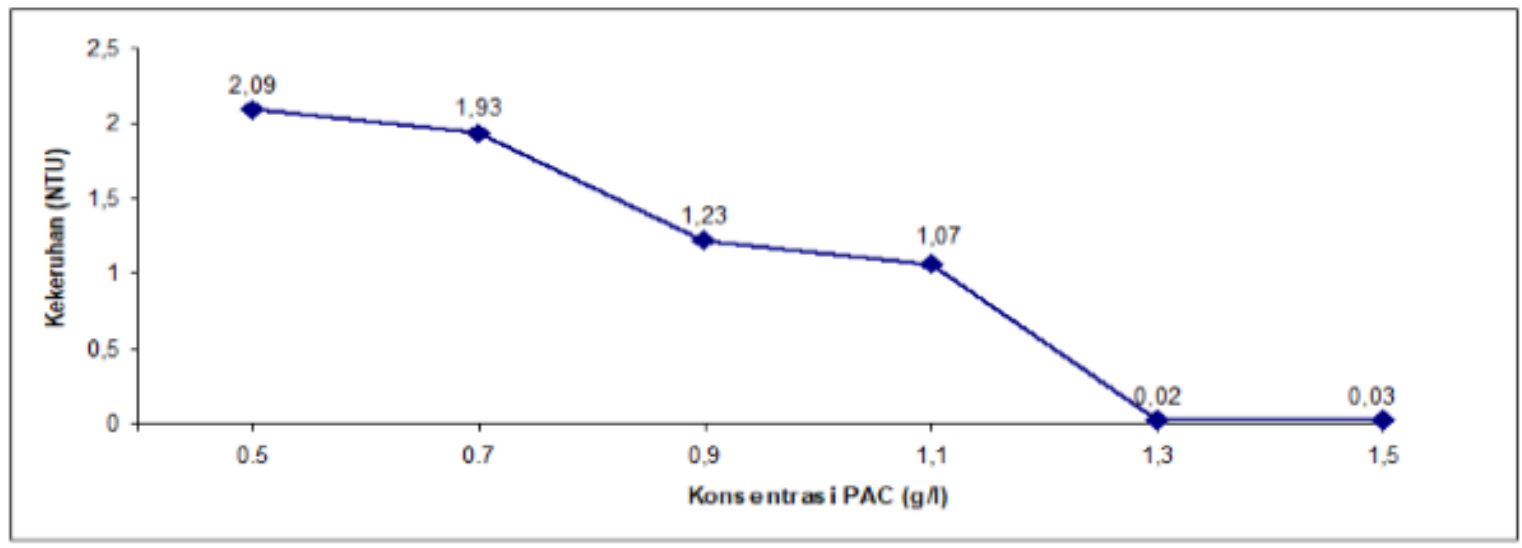

Gambar 4. Grafik Pengaruh Konsentrasi PAC Terhadap Kekeruhan

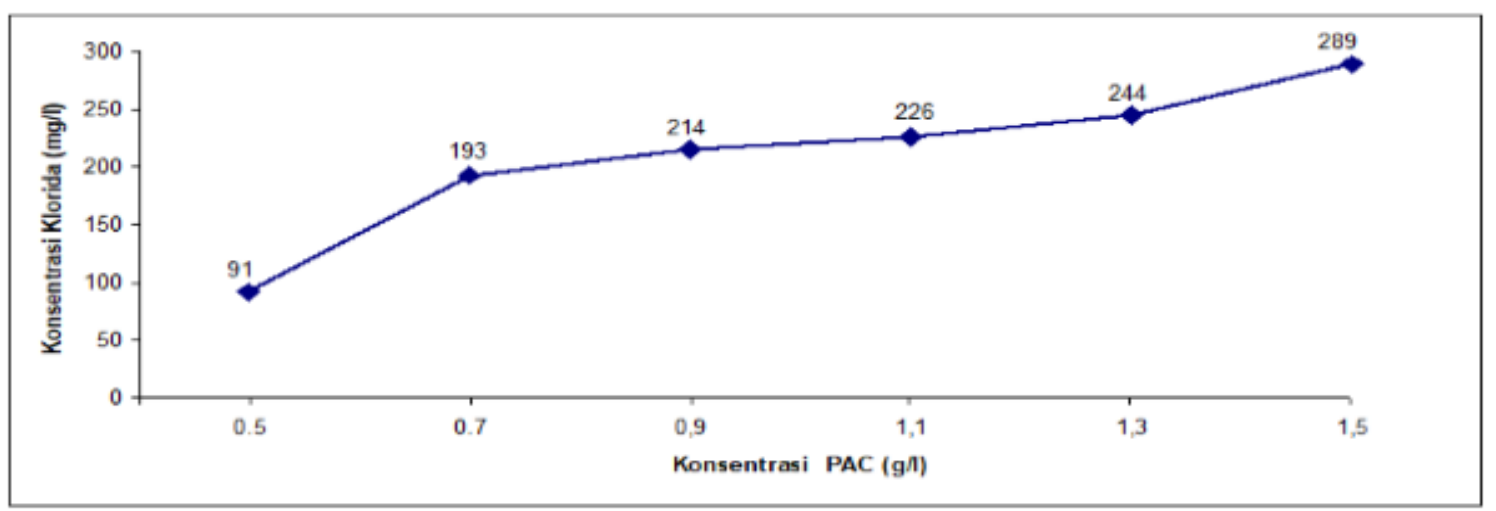

Gambar 5. Grafik Pengaruh Konsentrasi PAC Terhadap Konsentrasi Klorida 


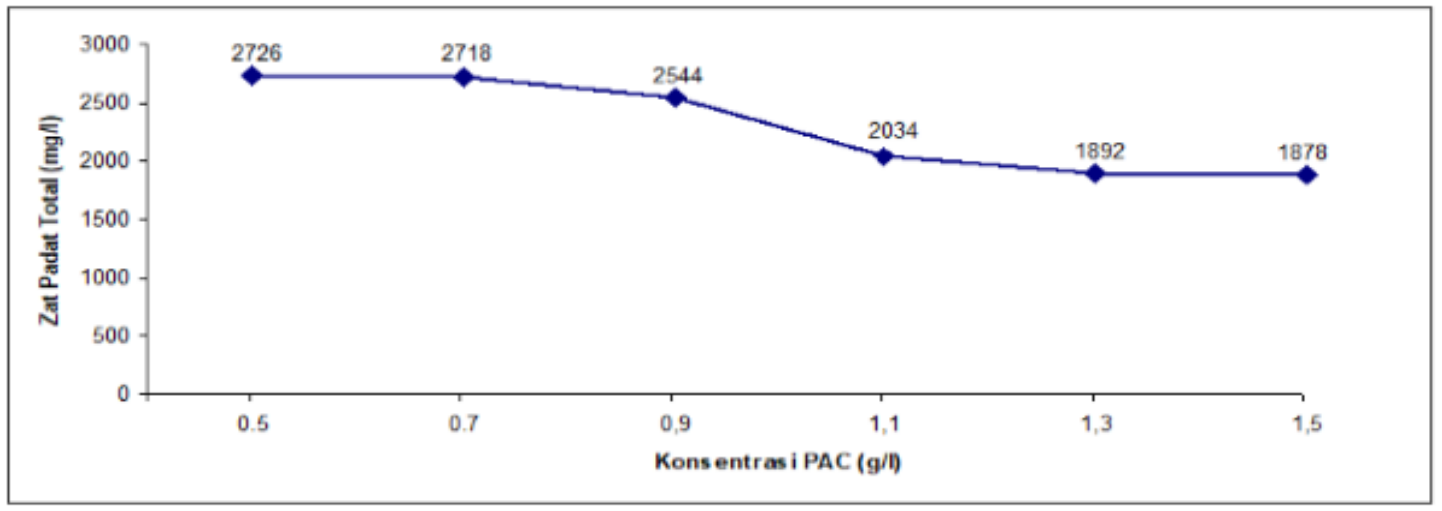

Gambar 6. Grafik Pengaruh Konsentrasi PAC Terhadap Konsentrasi Zat Padat Total

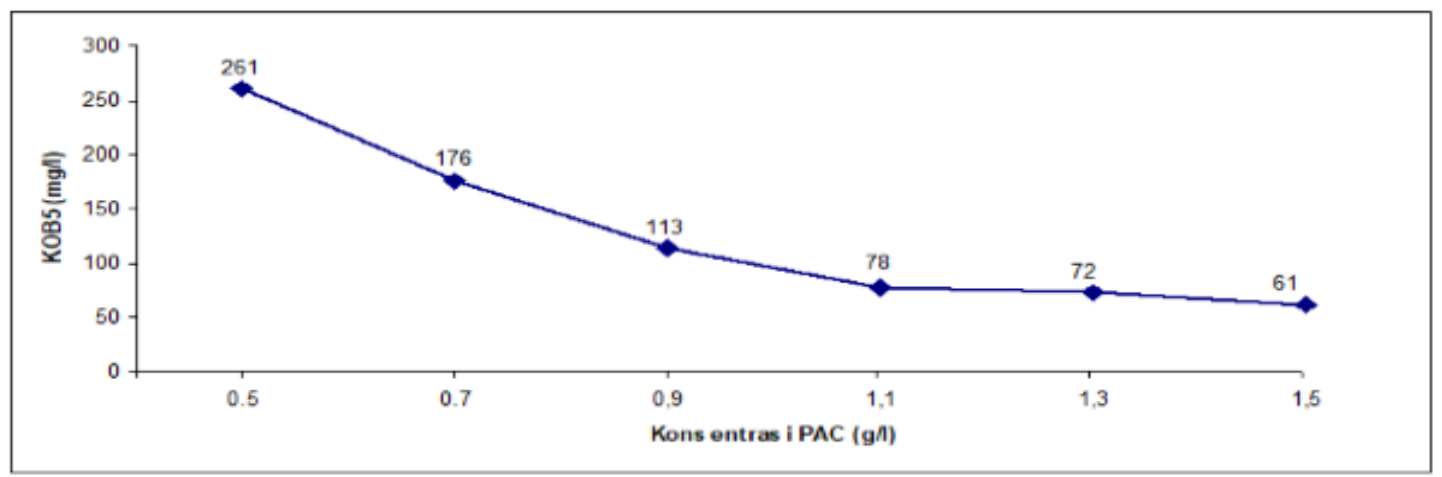

Gambar 7. Grafik Pengaruh Konsentrasi PAC Terhadap Konsentrasi KOB 5

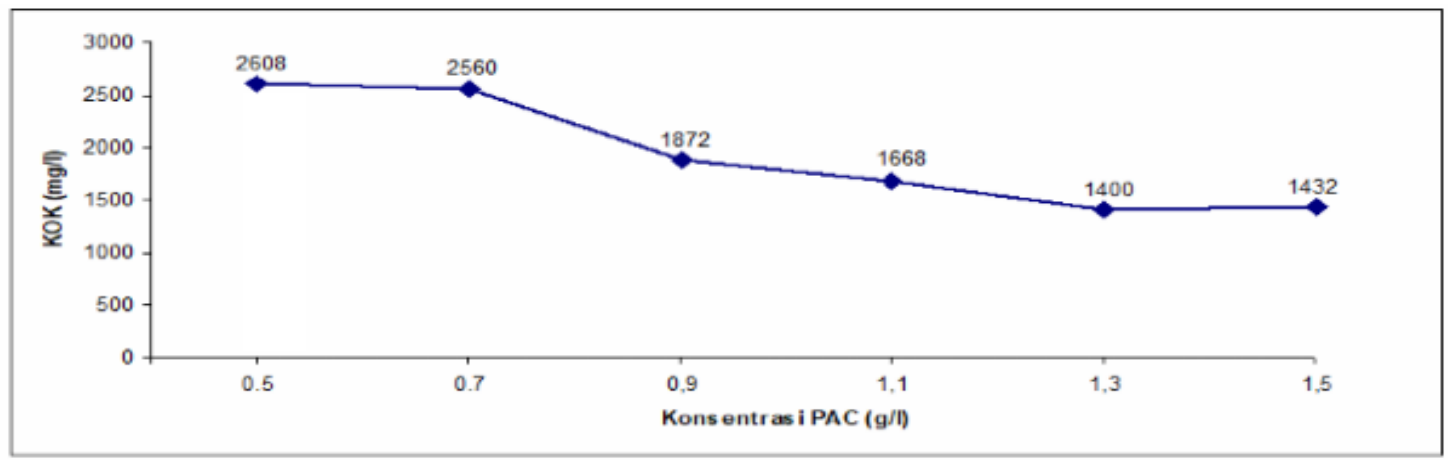

Gambar 8. Grafik Pengaruh Konsentrasi PAC Terhadap Konsentrasi KOK

Data hasil pengujian kain dapat dilihat pada Tabel 3 berikut:

Tabel 3. Data Hasil Pengujian Kain

\begin{tabular}{|l|c|c|c|c|}
\hline \multicolumn{1}{|c|}{ Pengujian } & Satuan & Air Proses & Air Olahan (1,3 g/I) & Air Buangan \\
\hline Pengurangan berat & $\%$ & 3,34 & 3,25 & 1,06 \\
\hline Derajat Putih $(\mathrm{Y})$ & - & 83,68 & 83,0 & 80,3 \\
\hline Beda Warna $(\mathrm{AE})$ & & & & 6,99 \\
\hline -Warna merah & & - & 1,99 & 8,69 \\
\hline -Warna biru & & - & 1,22 & 3,40 \\
\hline -Warna kuning & & - & 0,83 & \\
\hline
\end{tabular}

Keterangan : Kain yang dikerjakan dengan air proses dipakai sebagai pembanding 


\section{Pengujian Pengurangan berat}

Berdasarkan data pada Tabel 3. dapat dilihat persentase pengurangan berat untuk kain yang dikerjakan penghilangan kanjipemasakan (simultan)dengan air olahan adalah sebesar 3,25\% sedangkan jika pengerjaan penghilangan kanji dan pemasakan tersebut menggunakan air buangan (sebelum diolah), dihasilkan pengurangan berat $1,06 \%$. Dengan menggunakan air proses yang tersedia di pabrik sebegai standar pembanding dihasilkan pengurangan berat sebesar 3,34\% . Dapat diambil kesimpulan, bahwa air olahan ternyata efektif digunakan untuk proses penghilangan kanji dan pemasakan, terbukti dengan persentase pengurangan berat yang relatif sama. Pada proses penghilangan kanji dan pemasakan, alkali yang digunakan akan menyabunkan lemak, minyak, kotoran serta kanji poliakrilat pada kain. Demikian pula oksidator yang ada akan melarutkan kanji PVA pada kain. Jadi meskipun air yang di gunakan mengandung kanji PVA, namun tidak menghalangi kerja zat-zat yang diberikan pada proses penghilangan kanji dan pemasakan.

\section{Pengujian Derajat Kain Putih.}

Dari data yang terdapat pada Tabel 3. terlihat bahwa pada proses penghilangan kanji-pemasakan (simultan) dengan menggunakan air olahan derajat putih kain (Y) adala 3,62\%. Bila dibandingkan dengan grey akan menaikan derajat putih kain sebasar 3,62\%. Bila digunakan air sebelum diolah derajat putih kain (Y) adalah 80,3, dan kenikan derajat putih dibandingkan grey sebsar $0,25 \%$. Sedangkan bila digunakan air proses di pabrik sebagai standar pembanding, derajat putih kain (Y) adalah 83,68 dan menaikan derajat putih kain terhadap grey sebesar 4,46\%. Dari data tersebut menunjukan bahwa hasil pengerjaan penghilangan kanji dan pemasakan dengan menggunakan air olahan tidak begitu jauh perbedaanya dengan hasil pengerjaan penghilangan kanji dan pemasakan dengan air proses yang tersedia di pabrik (standar pembanding). dengan demikian dapat disimpulkan bahwa air olahan tersebut dapat digunakan untuk air proses penghilangan kanji dan pemasakan (simultan).

\section{Pengujian Beda Warna}

Dari data hasil pengujian pada Tabel 3. dapat dilihat bahwa hasil pencelupan untuk warna-warna tunggal yaitu, merah, biru, kuning, dengan menggunakan air olahan pada konsentrasi PAC optimum dan dengan menggunakan air proses yang tersedia di pabrik sebagai pembanding, ternyata beda warnanya tidak begitu jauh. Dimana nilai beda warna untuk warna merah terhadap standar pembanding $=1,79 ;$ biru $=1,22 ;$ dan kuning $=0,83$. sedangkan hasil pencelupan memggunakan air buangan terlihat jauh sekali pebedaannya, dimana nilai beda warna untuk warna merah $=6,99$; biru $=8,69$; dan kuning $=3,40$.

Meskipun hasil percobaan pencelupan dengan air olahan dengan konsentrasi PAC optimum cukup baik, dimana perbedaan warnanya cukup dekat dengan standar pembanding dalam arti sedikit lebih muda, namun bukan merupakan jaminan jika untuk produksi dilapangan akan dihasilkan hal yang sama atau tidak mengalami masalah. Dikarenakan nilai KOK dan zat padat total masih tetap tinggi, yang berarti masih terdapatnya kanji PVA pada larutan, kemungkinannya dapat mempengaruhi masuknya zat warna kedalam serat dan dapat mengakibatkan ketidakrataan hasil celupan atau warna celupan lebih muda dari yang diinginkan. Oleh karena itu pemakaian air olahan tersebut sebaiknya tidak digunakan untuk proses pencelupan, untuk menghindari hal-hal yang tidak diinginkan tersebut. 


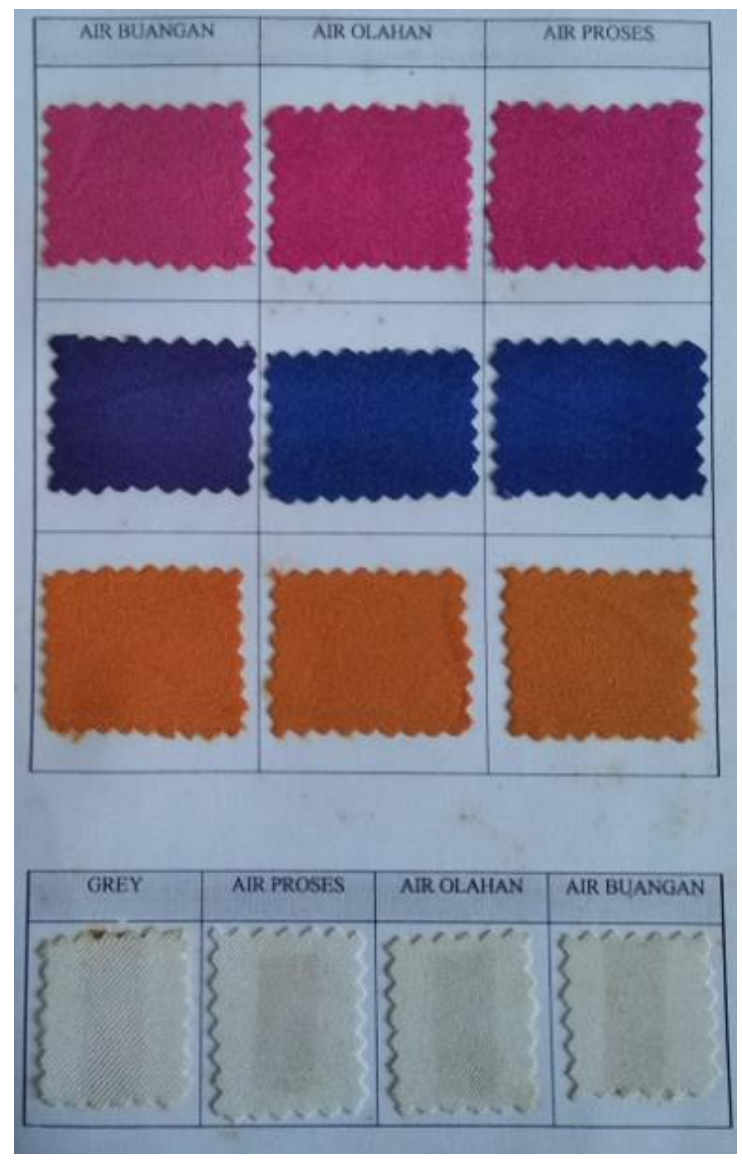

Gambar 9. Hasil Proses penghilangan kanji-pemasakan (simultan) dan Pencelupan

\section{Kesimpulan}

Ada beberapa kesimpulan yang diperoleh dalam penelitian ini, yaitu:

1. Konsentrasi PAC (Poli Alumunium Klorida) optimum adalah sebesar 1,3 g/l.

2. Air buangan proses relaksasipenghilangan kanji-pemasakan (simultan) yang diolah dengan cara koagulasi dapat digunakan untuk proses yang sama.

3. Air olahan tersebut sebaiknya tidak digunakan untuk proses pencelupan dikarenakan masih mengandung kanji PVA.

\section{Daftar Pustaka}

AWWA, 1971.Water Quality and
Treatment, MC-Graw Hill Book Company, Third Edition, New York.

Awad, Mohammed; Li, Fengting and

Hongtao, Wang. Application Of Natural Clays And Poly Aluminium Chloride (PAC) For Wastewater Treatment. IJRRAS Vol.15 issue 2, 2013.

Budiman, Anton, dkk, Kinerja Koagulan

Poly Aluminium Chloride (PAC)

Dalam Penjernihan Air Sungai

Kalimas Surabaya Menjadi Air Bersih. Widya Teknik Vol. 7, No. 1, 2008 (25-34).

Bapedal - BBT, Buku Panduan Teknologi

Pengendalian Dampak Lingkungan

Industri Tekstil, Kerjasama antara Badan Pengendalian Dampak Lingkungan dan Balai Besar Tekstil, Bandung 1994.

Husaini, Husaini; Cahyo, Stevanus; dkk.

Perbandingan Koagulan Hasil

Percobaan Dengan Koagulan

Komersial Menggunakan Metode Jar Test. Jurnal Teknologi Mineral dan Batubara Volume 14, Nomor 1, Januari $2018: 31-45$.

Ivory, Felicitas Tower, Studi Evaluasi

Bangunan Penglahan Air Ditinjau dari Penggunaaan Koagulan PAC Liquid, Tugas Akir ITB, 1994.

Kumar, $\mathrm{N}$ and Balasundaram, N, Efficiency

of PAC in Water Treatment Plant \& Disposal of Its Sludge, International Journal of Applied Engineering Research ISSN 0973-4562 Volume 12, Number 12 (2017) pp. 3253-3262 (C) Research India Publications. http://www.ripublication.com.

Peavy, S.H., Rowe, D.R., Tchobanoglous,

G., Environmental Engineering, McGraw Hill Corp, New York, 1985 